\title{
Mechanical Correction and Chemical Avoidance of Circling Roots Differentially Affect Post-transplant Root Regeneration and Field Establishment of Container-grown Shumard Oak
}

\author{
Michael A. Arnold ${ }^{1}$ \\ Department of Horticultural Sciences, Texas A\&M University, College Station, TX 77843-2133 \\ Additional index words. Quercus shumardii, container production, copper hydroxide, root pruning, seedling establishment
}

\begin{abstract}
Quercus shumardii Buckl. seedlings were grown for 3 or 7 months in 2.3-liter black plastic containers. Containers were either treated or not on interior surfaces with $100 \mathrm{~g} \mathrm{Cu}(\mathrm{OH})_{2}$ /liter latex carrier. Trees were transplanted in summer or fall to quantify post-transplant responses to mechanical correction or chemical prevention of circling roots. Four treatments were used at each transplant date; nonpruned seedlings from $\mathrm{Cu}(\mathrm{OH})_{2}$-treated or nontreated containers, and seedlings from nontreated containers in which two mechanical root pruning techniques were used, traditional severing of circling roots on the rootball periphery or splitting and splaying the bottom two-thirds of the rootball at transplant (butterfly pruning). Traditional root pruning severed more small-diameter roots $(\leq 0.5 \mathrm{~mm})$, while butterfly pruning severed more large-diameter roots. During the first 21 days following transplant most root regeneration was via elongation of intact root tips. $\mathrm{Cu}(\mathrm{OH})_{2}$-treated seedlings regenerated substantially more roots $\leq 1.0 \mathrm{~mm}$ in diameter and a greater root mass than mechanically root pruned or nonpruned seedlings. Both corrective mechanical pruning techniques resulted in greater predawn water stress during immediate post-transplant (21 days) establishment in October than seedlings chemically treated to prevent circling root development. Treatments that severed more roots and/or removed greater root mass were associated with decreased field performance and increased post-transplant water stress. Increased numbers of small- to medium-diameter new roots were associated with reduced post-transplant water stress and improved posttransplant shoot growth. Nonpruned and traditional root pruned seedlings grew little during the first two post-transplant growing seasons regardless of transplant date. Butterfly pruning resulted in severe dieback of shumard oak seedlings. $\mathrm{Cu}(\mathrm{OH})_{2}$-treated seedlings were the only ones to exhibit a gain in height or stem diameter after 2 years in the field.
\end{abstract}

It has long been recognized that circling roots have the potential to adversely affect tree health and/or stability. Root restriction is an inherent problem with container-grown trees. With the increasing popularity of container-grown trees, landscapers, arborists, and landscape architects have become increasingly concerned with the potential for girdling roots (Appleton, 1993; Siebenthaler, 1993). Mechanical remediation of circling roots at transplanting has become a standard practice (Harris, 1992), although increased symptoms of transplant shock during field establishment can occur (Arnold and Struve, 1989b; Struve, 1993). Mechanical remediation of circling roots is typically accomplished at transplanting by making several vertical cuts down the exterior of the rootball (Gouin, 1983; Harris, 1992). Butterfly pruning (splitting and splaying apart the lower two-thirds of the rootball) has been suggested for planting sites with compacted or poorly drained soils (Gouin, 1983; Harris, 1992).

Chemical avoidance or reduction of circling roots via application of $\mathrm{Cu}$ to interior surfaces of containers before production has proven to be effective with many species (Beeson and Newton, 1992; Arnold and Struve, 1993; Struve et al., 1994). Effects of Cu-

Received for publication 29 June. Accepted for publication 29 Oct. 1995. Experiments were funded by the Texas Agricultural Experiment Station and Texas A\&M Univ. I thank Larry J. Shoemake (graduate student) and Vicky L. Barnett (undergraduate student) for their technical assistance and the Griffin Corp., Greenleaf Nursery Co., and Lerio Corp., for donation of chemicals, plants, and containers, respectively. Mention of a trademark, proprietary product, or vendor does not constitute a guarantee or warranty of the product and does not imply its approval to the exclusion of other products or vendors that also may be suitable. The cost of publishing this paper was defrayed in part by the payment of page charges. Under postal regulations, this paper therefore must be hereby marked advertisement solely to indicate this fact.

${ }^{1}$ Assistant professor. treated containers on root growth during container production have been well documented. Copper-treated containers decrease circling, matted, and kinked roots at the container wall-media interface (Arnold and Struve, 1989a, 1989b, 1993; Beeson and Newton, 1992; Svenson and Brochat, 1992), increase root branching (Arnold and Struve, 1989a), increase the number of actively growing root tips (Arnold and Young, 1991), increase the uniformity of root distribution within the rootball (Arnold and Struve, 1993; Vartak, 1993), and in some species increase shoot extension, stem diameter, or dry matter accumulation (Arnold and Struve, 1989a, 1989b; Beeson and Newton, 1992; Ruter, 1994; Svenson et al., 1995). Improved plant water relations during container production have been demonstrated for tropical hibiscus (Hibiscus rosasinensis L., Case and Arnold, 1993) and red tip photinia (Photinia $\times$ fraseri Dress, Vartak, 1993) grown in Cu-treated containers versus those in nontreated containers. Quercus acutissima Carruth. seedlings grown in $\mathrm{Cu}$-treated containers had greater uptake of mineral nutrients (Arnold and Struve, 1993).

Few studies have investigated post-transplant growth responses of woody plants grown in Cu-treated containers. Enhanced growth or survival have been reported for some trees produced in $\mathrm{Cu}$ treated containers over those from nontreated containers (Arnold and Struve, 1989b; Struve, 1993, 1994). Production of some species in $\mathrm{Cu}$-treated containers has enhanced flowering following transplanting (Arnold et al., 1993; Svenson and Johnston, 1995). A greater root mass outside the original rootball (Arnold and Struve, 1989b) was associated with trees transplanted from $\mathrm{CuCO}_{3}-$ treated versus nontreated containers, but to date root morphology, the phenology of root growth and water relations have not been investigated. Detailed characterization of alternative techniques for mechanical correction and chemical avoidance of circling roots on root regeneration and their relationship to plant water status and 
transplant establishment are lacking.

The objective of this study was to characterize the effects of alternative chemical avoidance and mechanical correction of circling roots on the post-transplant relationships among the rate, size and spacial distribution of regenerated roots, leaf water potential, and subsequent field performance of container-grown shumard oaks.

\section{Materials and Methods}

Production conditions. In March 1993, 80 Q. shumardii seedlings (10 to $15 \mathrm{~cm}$ tall, Greenleaf Nursery Co., Houston, Texas) were planted in 2.3-liter black plastic containers (Lerio Corp., El Campo, Texas) containing a 3 pine bark: 1 sand (by volume) medium amended with $3.5 \mathrm{~kg}$ dolomite, $1.75 \mathrm{~kg}$ gypsum, and 0.86 kg Micromax trace elements (Sierra Chemical Co., Milpitas, Calif.) per $\mathrm{m}^{3}$. Twenty containers were treated on interior surfaces with $\mathrm{Cu}(\mathrm{OH})_{2}$ at the rate of $100 \mathrm{~g} \cdot \mathrm{liter}^{-1}$ latex carrier (SpinOut, Griffin Corp., Houston, Texas) before planting, 60 were not treated. Containers were placed on $75-\mathrm{cm}$-tall benches in a greenhouse with day/night temperatures set at 22/16C. Natural photoperiods were interrupted from 0000 to $0400 \mathrm{HR}$ using 40-W incandescent bulbs suspended $1 \mathrm{~m}$ apart and $0.5 \mathrm{~m}$ above the bench-top. Sixteen grams of $18 \mathrm{~N}-3.1 \mathrm{P}-8.3 \mathrm{~K}-1 \mathrm{Fe}$ slow-release fertilizer (Sierrablen, O.M. Scotts, Marysville, Ohio) were placed on the medium surface of each container. Seedlings were hand watered as needed and fertigated weekly with $200 \mathrm{mg}$ N/liter from a 24N3.5P-13K water soluble complete fertilizer (O.M. Scotts). On 5 May 1993, seedlings were moved outdoors under 55\% light exclusion. Irrigation was applied via spot spitters (Roberts Irrigation Products, San Marcos, Calif.) and weekly fertigation continued as before. Seedlings were staked and trained to a central leader.

Greenhouse studies. On 6 June and 11 Oct. 1993, twenty seedlings, five grown in $\mathrm{Cu}(\mathrm{OH})_{2}$-treated containers and fifteen from nontreated containers, were transplanted to rectangular root observation boxes $(22 \times 22 \times 28 \mathrm{~cm})$ with plexiglas side and bottom panels (five $0.75-\mathrm{cm}$ drainage holes) and wood frames of $2.5-\mathrm{cm}$ quarter-round exterior-treated wood molding, containing 13 liters of the pine bark-sand medium. Seedlings from nontreated containers were divided into three groups. Five seedlings were not root pruned at transplanting. The rootballs of five seedlings were split in half vertically for two-thirds of their height from bottom to top and the split halves splayed apart (butterfly root pruning, Gouin, 1983). The remaining seedlings were root pruned by making four evenly distributed vertical slits $1 \mathrm{~cm}$ deep from top to bottom on the exterior of the rootball and removing matted roots at the bottom of the container (traditional root pruning, Bush-Brown and BushBrown, 1980). Dry weights (5 days at 70C) of severed portions of roots that could be removed without further disturbing the rootball were recorded. The diameter of all pruned roots were measured at the point of severance.

Exterior surfaces of rootballs were sprayed with $5 \mathrm{~g}$ methylene blue/liter water before transplanting to assist in distinguishing roots present at planting from subsequently regenerated roots (Arnold and Young, 1990). The mean distance from the transplanted rootball to the observation panels was $8.6 \mathrm{~cm}$. Root observation boxes were placed inside two 4-mil black plastic trash bags drawn to within $3 \mathrm{~cm}$ of the base of the plants. The individual plant replicates were arranged in a completely randomized design. Greenhouse conditions and culture were as described above. Temperatures were monitored using a Oaklon hygrothermograph (model 08369-70; Cole-Parmer Instr. Co., Chicago). Maximum deviations from day/night set points for temperatures and relative humidity (max./min.) were June, 33/17C, 83\%/59\%, and October, 28/12C, $85 \% / 63 \%$.

Midday (1230 to $1330 \mathrm{HR}$ ) and subsequent predawn (0400 to $0530 \mathrm{HR}$ ) xylem water potentials $(\psi)$ of the most recently fully expanded leaf from each seedling were measured using a pressure chamber (model 610; PMS Instrument Co., Corvallis, Ore.) at transplanting and 1, 3, 7, 14, and 21 days after. At 3-day intervals (through 21 days after transplanting), live root (no evidence of decay, tips white to light brown) extension was traced on clear acetate sheets placed against the observation panels. The terminal location of the tip was marked with the date and roots were labeled as small $(\leq 0.5 \mathrm{~mm}$ in diameter) or large $(>0.5 \mathrm{~mm}$ in diameter). Information on higher order lateral roots branching from traced roots was not recorded. Root tracings were used to calculate root extension rates and to estimate sectors of origin of regenerated roots. Root observation surfaces were divided into four equal quadrants to estimate the spatial distribution of regenerated roots.

Table 1. Growth effects of significant interactions among transplanting time and root pruning treatments on shumard oak seedlings during the first 3 weeks following transplanting to root observation boxes in a greenhouse and during two growing seasons in the field. ${ }^{\mathrm{Z}}$

\begin{tabular}{|c|c|c|c|c|c|c|c|}
\hline \multirow[b]{4}{*}{$\begin{array}{l}\text { Month of } \\
\text { transplanting }\end{array}$} & \multirow[b]{4}{*}{$\begin{array}{c}\text { Root } \\
\text { pruning }\end{array}$} & \multicolumn{5}{|c|}{ Greenhouse responses } & \multirow{4}{*}{$\begin{array}{c}\text { Field responses } \\
\text { Shoot growth }^{\mathrm{w}} \\
\text { year } 2 \\
(\mathrm{~cm})\end{array}$} \\
\hline & & \multirow{3}{*}{$\begin{array}{l}\text { Total } \\
\text { plant } \\
\text { dry } \\
\text { wt }(g)\end{array}$} & \multirow{3}{*}{$\begin{array}{l}\text { Pruned } \\
\text { root } \\
\text { dry } \\
\text { wt }(g)\end{array}$} & \multicolumn{3}{|c|}{ Root regeneration outside original rootball } & \\
\hline & & & & \multirow{2}{*}{$\begin{array}{c}\text { Root } \\
\text { extension }^{\mathrm{x}} \\
(\mathrm{cm} / \text { day })\end{array}$} & \multicolumn{2}{|c|}{ Contact on observation panels } & \\
\hline & & & & & $\begin{array}{l}\text { Upper half } \\
\text { (no./plant) }\end{array}$ & $\begin{array}{l}\text { Lower half } \\
\text { (no./plant) }\end{array}$ & \\
\hline \multirow[t]{4}{*}{ June } & Nonpruned & $8.27 \mathrm{c}^{\mathrm{y}}$ & $0.00 \mathrm{c}$ & $0.83 \mathrm{a}$ & $7 \mathrm{ab}$ & $26 \mathrm{bc}$ & $-10 \mathrm{bc}$ \\
\hline & Traditional & $7.12 \mathrm{c}$ & $0.37 \mathrm{~b}$ & $0.64 \mathrm{bc}$ & $3 \mathrm{~b}$ & 14 cde & $-4 a b$ \\
\hline & Butterfly & $9.17 \mathrm{c}$ & $0.37 \mathrm{~b}$ & $0.73 \mathrm{ab}$ & $3 \mathrm{~b}$ & $32 \mathrm{~b}$ & $-5 \mathrm{ab}$ \\
\hline & Cupric hydroxide & $12.74 \mathrm{c}$ & $0.00 \mathrm{c}$ & $0.58 \mathrm{~cd}$ & $7 \mathrm{ab}$ & $51 \mathrm{a}$ & $10 \mathrm{a}$ \\
\hline \multirow[t]{4}{*}{ October } & Nonpruned & $37.98 \mathrm{~b}$ & $0.00 \mathrm{c}$ & 0.52 cde & $11 \mathrm{ab}$ & $5 \mathrm{de}$ & $5 \mathrm{a}$ \\
\hline & Traditional & $33.48 \mathrm{~b}$ & $0.84 \mathrm{~b}$ & 0.55 bcde & $7 \mathrm{ab}$ & $4 \mathrm{e}$ & $-1 \mathrm{ab}$ \\
\hline & Butterfly & $42.33 \mathrm{~b}$ & $1.63 \mathrm{a}$ & $0.47 \mathrm{de}$ & $14 \mathrm{a}$ & $5 \mathrm{de}$ & $-22 c$ \\
\hline & Cupric hydroxide & $60.76 \mathrm{a}$ & $0.00 \mathrm{c}$ & $0.44 \mathrm{e}$ & $16 \mathrm{a}$ & $22 \mathrm{bcd}$ & $10 \mathrm{a}$ \\
\hline
\end{tabular}

${ }^{\mathrm{z}}$ Values are means of observations from five plants.

${ }^{y}$ Means within a column followed by the same letter are not significantly different at $P \leq 0.05$ using least squares means procedure.

${ }^{x}$ Regenerated roots $>0.5 \mathrm{~mm}$ in diameter contacting root observation panels.

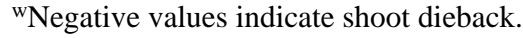


Table 2. Main effects of root pruning treatments on shumard oak seedlings during the first 3 weeks following transplanting to root observation boxes in a greenhouse or two growing seasons in the field. ${ }^{\mathrm{z}}$

\begin{tabular}{|c|c|c|c|c|c|c|c|c|}
\hline \multirow[b]{3}{*}{$\begin{array}{l}\text { Root pruning } \\
\text { treatment }\end{array}$} & \multicolumn{3}{|c|}{ Greenhouse responses } & \multicolumn{5}{|c|}{ Field responses } \\
\hline & \multicolumn{2}{|c|}{ At transplant } & \multirow{2}{*}{ 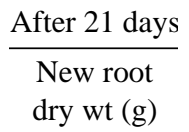 } & \multirow{2}{*}{$\begin{array}{c}\text { Ht at } \\
\text { transplant } \\
(\mathrm{cm})\end{array}$} & \multicolumn{2}{|c|}{ 2-Year total } & \multicolumn{2}{|c|}{ Net change } \\
\hline & $\begin{array}{l}\mathrm{Ht} \\
(\mathrm{cm})\end{array}$ & $\begin{array}{l}\text { Stem diam } \\
\quad(\mathrm{mm})\end{array}$ & & & $\begin{array}{l}\mathrm{Ht} \\
(\mathrm{cm})\end{array}$ & $\begin{array}{l}\text { Stem diam } \\
(\mathrm{mm})\end{array}$ & $\begin{array}{l}\mathrm{Ht} \\
(\mathrm{cm})\end{array}$ & $\begin{array}{l}\text { Stem diam } \\
\quad(\mathrm{mm})\end{array}$ \\
\hline Nonpruned & $61 b^{y}$ & $7.6 \mathrm{~b}$ & $0.87 \mathrm{~b}$ & $50 \mathrm{~b}$ & $40 \mathrm{~b}$ & $7.1 \mathrm{~b}$ & $-10 b c$ & $0.1 \mathrm{ab}$ \\
\hline Traditional & $63 \mathrm{~b}$ & $7.5 \mathrm{~b}$ & $0.44 \mathrm{~b}$ & $45 \mathrm{~b}$ & $43 \mathrm{~b}$ & $5.9 \mathrm{c}$ & $-2 a b$ & $-0.1 \mathrm{~b}$ \\
\hline Butterfly & $68 \mathrm{~b}$ & $8.1 \mathrm{~b}$ & $0.78 \mathrm{~b}$ & $43 \mathrm{~b}$ & $18 \mathrm{c}$ & $4.8 \mathrm{c}$ & $-24 c$ & $-2.2 b$ \\
\hline Cupric hydroxide & $84 \mathrm{a}$ & $8.8 \mathrm{a}$ & $2.09 \mathrm{a}$ & $83 \mathrm{a}$ & $93 \mathrm{a}$ & $9.1 \mathrm{a}$ & $10 \mathrm{a}$ & $2.9 \mathrm{a}$ \\
\hline
\end{tabular}

${ }^{\mathrm{z} V a l u e s}$ are means of observations on 10 plants.

${ }^{\mathrm{y}}$ Means within a column followed by the same letter are not significantly different at $P \leq 0.05$, least squares means procedure.

Height and stem diameter were recorded at $0,1,3,7,14$, and 21 days after transplant.

At 21 days after transplanting, seedlings were harvested to determine the dry weight of shoots, roots inside the original rootball (predominantly roots present at transplanting), and regenerated roots outside the transplanted rootball. A subsample of regenerated roots was used to determine mean diameters of regenerated roots and the diameters of the roots from which the regenerated roots originated. Regenerated roots were separated into several size classes. If 50 roots per plant were regenerated, all regenerated roots were measured; if $>50$ roots but 100 roots were regenerated, then every fifth root was measured; if $\leq 100$ roots were regenerated, then every tenth root was measured. The diameters of regenerated roots were measured at the midpoint of the length of the root.

The following method was used to estimate the diameter of the roots from which new roots were regenerated (origin of regenerated roots). If roots were initiated adventitiously from roots pruned at transplanting, the diameter of pruned roots were measured at the point of attachment of adventitious roots. The diameter of regenerated roots originating as elongation of intact roots at transplanting were measured at the point of origin from the original rootball or the demarcation between dyed and nondyed root tissue for roots that were at the surface of the rootball at transplanting.

Field studies. Companion plantings to the greenhouse studies of five plants per treatment combination and transplant date were established at $1 \mathrm{~m}$ within row and $3 \mathrm{~m}$ between row spacings (completely randomized design) in a field plot (College Station, Texas, Boonville Series, Boonville fine sandy loam, $61 \%$ sand, $11 \%$ clay, $28 \%$ silt, fine, montmorillonitic, thermic ruptic-vertic albaqualfs, $\mathrm{pH} 8.9$, bulk density $1.50 \mathrm{~g} \cdot \mathrm{cm}^{-3}$ ). Root pruning treatments were applied and seedlings transplanted as previously described, except root dye was omitted. Drip irrigation was provided daily for the first week, on alternate days the second week, twice weekly the following four weeks, and weekly thereafter during the growing season when natural rainfall was $<3 \mathrm{~cm} /$ week. In March 1994, $16 \mathrm{~g}$ of the $18 \mathrm{~N}-3.1 \mathrm{P}-8.3 \mathrm{~K}-1 \mathrm{Fe}$ slow-release fertilizer were applied to the soil surface below the drip line of each seedling. Height $(\mathrm{cm})$ and stem diameter $(\mathrm{mm})$ at $5 \mathrm{~cm}$ above the soil surface were assessed at transplanting and just before autumn leaf senescence in October 1993 and 1994.

An analysis of variance was performed on the data using the general linear models procedures in PC-SAS (SAS Institute, Cary, N.C.). A completely random statistical design was used during production and in the greenhouse and field studies. Significant $(P$ $<0.05$ ) interactions, and main effects not involved in significant interactions, were further analyzed using least squares means, frequency, and/or polynomial regression procedures.

\section{Results and Discussion}

Production responses. By fall transplanting, seedlings grown in $\mathrm{Cu}(\mathrm{OH})_{2}$-treated containers had greater dry weight (Table 1) than those from nontreated containers and had greater height and stem diameter across transplant times (Table 2). Similar growth increases during container production have been reported for other Quercus spp. grown in $\mathrm{Cu}(\mathrm{OH})_{2}$-treated containers (Arnold, 1992; Arnold and Struve, 1993; Beeson and Newton, 1992). Quercus shumardii shoot extension is via recurrent flushes. About half ( 8 greenhouse, 10 field) of the seedlings were in an active growth flush at the June transplant while no terminal buds were expanding during the October transplant. Seedlings transplanted in October were substantially larger than those transplanted in June (Table 1).

Greenhouse studies. A greater root mass was severed by the root pruning treatments in October than in June (Table 1). Traditional and butterfly root pruning resulted in removal of similar masses of roots in June while the butterfly technique removed a greater root mass in October (Table 1). However, the number of roots severed per plant by mechanical pruning practices in June (Fig. 1) were greater than in October. Traditional root pruning severed more small $(\leq 1.5 \mathrm{~mm}$ in diameter) roots than butterfly

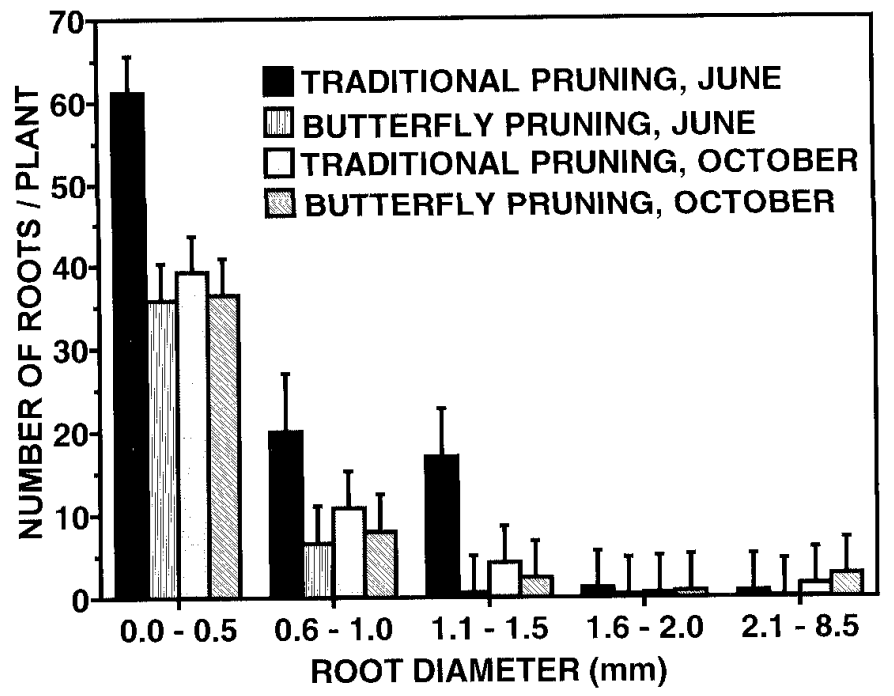

Fig. 1. Mean number ( \pm standard error) of roots of various diameters severed per plant using two mechanical root pruning methods to correct circling roots on 2.3liter rootballs of container-grown Quercus shumardii seedlings transplanted in June or October. Values are the means of observations on five plants per treatment. 

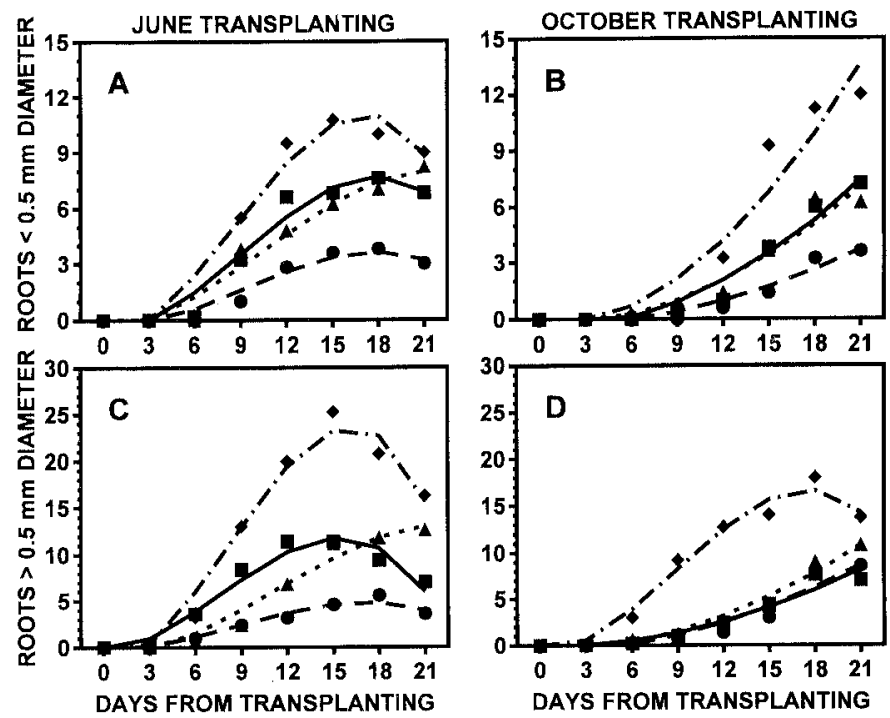

Fig. 2. Plots of significant $(P \leq 0.01)$ polynomial regression equations $\left(R^{2}\right.$ from 0.98 to 0.93 ) and observed means for the number of nonsuberized elongating root tips per plant of small $(\leq 0.5 \mathrm{~mm}, \mathbf{A}$ and $\mathbf{B})$ and large diameter roots $(>0.5 \mathrm{~mm}, \mathbf{C}$ and D) visible at observation panels for Quercus shumardii seedlings transplanted from 2.3-liter containers in June (A and $\mathbf{C})$ or October (B and D). Seedlings were grown in nontreated containers, and either root pruned to correct circling root development by traditional $(\mathbf{O})$ or butterfly $(\boldsymbol{\Delta})$ root pruning or not $(\mathbf{\square})$, or grown in $\mathrm{Cu}(\mathrm{OH})_{2}$-treated $(\diamond)$ containers to avoid circling root development.

pruning in June, while in October similar numbers of small roots were severed (Fig. 1). The discrepancy between root mass (Table 1) and number data (Fig. 1) could be attributed to pruning a greater number of roots $\leq 1.5 \mathrm{~mm}$ in diameter in June, while in October a greater proportion of pruned roots were of larger diameter (Fig. 1), particularly with butterfly pruning. Mechanical root pruning relative to nonpruned seedlings had no impact on the mass of regenerated roots during the first 21 days following transplanting, whereas $\mathrm{Cu}(\mathrm{OH})_{2}$-treated seedlings regenerated more than twice the mass of new roots of other treatments (Table 2).

Roots first appeared within 3 days for both root diameter classes and transplant dates (Fig. 2). However, more roots appeared in June than in October within nine to twelve days of transplant (Fig. 2). Traditional root pruning reduced the number of small diameter roots regenerated (Fig. 3A) compared to other treatments in June. Nonpruned and mechanically root pruned seedlings required longer to have a given number of roots present at observation panels compared to $\mathrm{Cu}(\mathrm{OH})_{2}$-treated seedlings (Fig. $2 \mathrm{~A}-$ D). This appeared to be due to a difference in the total number of roots regenerated rather than a difference in the rate of root elongation, as no treatment differences were found for elongation rates of roots $\leq 0.5 \mathrm{~mm}$ in diameter in June or October (data not presented), and nonpruned and butterfly pruned seedlings had greater mean daily rates of elongation of roots $>0.5 \mathrm{~mm}$ in diameter than did traditionally pruned or $\mathrm{Cu}(\mathrm{OH})_{2}$-treated seedlings in June (Table 1). The slower rates of elongation of roots $>0.5 \mathrm{~mm}$ diameter on $\mathrm{Cu}(\mathrm{OH})_{2}$-treated seedlings may have been due to a carry over of $\mathrm{Cu}$ inhibition of root elongation, but root elon-

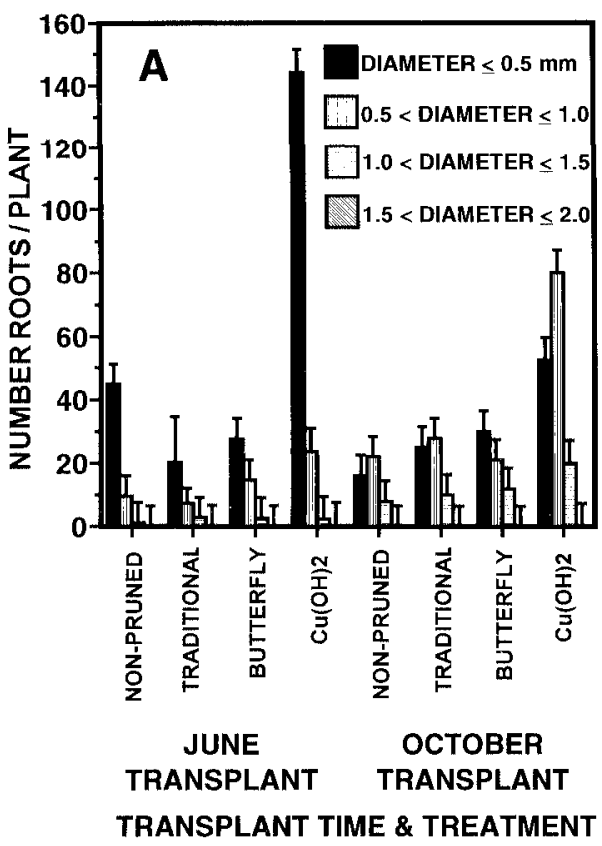

gation of Fraxinus pennsylvanica Marsh. inhibited by a mild $\mathrm{Cu}$ toxicity (from $\mathrm{CuCO}_{3}$ ) returned to similar elongation rates as nonexposed roots following removal of the source of the $\mathrm{Cu}$ exposure (Arnold and Struve, 1989a). Internal competition for available growth substances within the entire plant and within the root system occurs, particularly under limiting conditions (Brouwer, 1983). Slower root elongation rates for $\mathrm{Cu}(\mathrm{OH})_{2}$-treated seedlings could have been due to the much greater number of roots (Fig. 3) competing for photosynthates.

More regenerated roots were $\leq 0.5 \mathrm{~mm}$ in diameter in June, while roots of $<0.5$ to $\leq 1.5 \mathrm{~mm}$ in diameter constituted most roots regenerated in October (Fig. 3A). Most roots emerging from the rootball into the surrounding planting media originated from nondamaged roots present at planting (Fig. 3B). Most new roots originating from pruned roots were $\leq 0.5$ to $\leq 1.5 \mathrm{~mm}$ in diameter for traditional and butterfly pruned seedlings (Fig. 3B). The small number of regenerated roots, $0.5 \mathrm{~mm}$ in diameter from pruned roots present on nonpruned seedlings (Fig. 3B) were a result of root initiation from small roots at the exterior of the rootball that were unintentionally damaged during the transplanting process. $\mathrm{Cu}(\mathrm{OH})_{2}-$ treated seedlings regenerated substantially more roots than nonpruned and mechanically root pruned seedlings in both June and October (Fig. 3A). While much of this increase was a result of an increase in the number of roots $\leq 0.5 \mathrm{~mm}$ in diameter, an increase in the regeneration of roots between 0.6 and $1.5 \mathrm{~mm}$ in diameter was also evident, particularly in October (Fig. 3A).

The vertical (Table 1), but not horizontal (data not presented), distribution of regenerated roots was affected by treatments. The number of roots contacting both the upper and lower halves of the observation panels for $\mathrm{Cu}(\mathrm{OH})_{2}$-treated seedlings was equal to or greater than that of other treatments (Table 1). In June roots

Fig. 3. Mean number ( \pm standard error) of roots of various diameters that elongated beyond the transplanted 2.3-liter rootball of Quercus shumardii seedlings grown in $\mathrm{Cu}(\mathrm{OH})_{2}$-treated or nontreated containers or root pruned using traditional or butterfly pruning techniques at transplanting. Roots were separated into diameter classes based on season of transplant (A) or on origin from intact (nondamaged) roots or from roots that were severed or damaged (pruned) during the pruning and/ or transplanting process $(\mathbf{B})$. 
contacting the lower half of the panels constituted $83 \%$ to $87 \%$ of the roots for all treatments (Table 1). In October over half of the roots for nonpruned and mechanically pruned seedlings were in the top half of the profile while more regenerated roots of $\mathrm{Cu}(\mathrm{OH})_{2}$ treated seedlings contacted observation panels in the lower half of the profile (Table 1). Previous studies have documented alterations in root distribution while plants were in $\mathrm{Cu}(\mathrm{OH})_{2}$-treated containers (Arnold and Struve, 1993; Gilman and Beeson, 1995; Vartak, 1993). The present study suggests that the changes in vertical distribution of the root system may carry over to the early phases of field establishment.

In the greenhouse, shoot elongation continued during the 21 days following June transplanting ( $14 \mathrm{~cm}$ mean elongation), but in October terminal buds did not elongate. Midday leaf $\psi$ were more negative in June than October (Fig. 4 A vs. B). Moisture stress levels that induced stomatal closure were not determined for the $Q$. shumardii seedlings used in this study, but Beeson (1994) reported that reductions in stomatal conductance of live oak $(Q$. virginiana Mill.) did not occur until the stem $\psi$ were more negative than -1.8 $\mathrm{MPa}$. Midday $\psi$ approached this level only at 14 and 21 days after June transplant (Fig. 4 A and B), suggesting low moisture stress conditions in the greenhouse studies. No consistent pruning treatment differences were observed for midday $\psi$ (Fig. 4 A and B).

Interestingly, June transplanted seedlings exhibited better recovery from the previous day's water stress as measured by predawn $\psi$ (Fig. 4C) than did October transplanted seedlings (Fig. 4D), particularly for mechanically pruned seedlings. Predawn $\psi$ of $\mathrm{Cu}(\mathrm{OH})_{2}$-treated seedlings indicated better recovery from the previous day's water stress than other treatments on most days following October transplant (Fig. 4D). A similar but less pronounced trend was apparent in June (Fig. 4C). Mechanical root pruning appeared to hamper predawn $\psi$ recovery most in October (Fig. 4D), corresponding to the greatest removal of root mass (Table 1) and proportion of roots $>1.5 \mathrm{~mm}$ in diameter pruned at transplant by mechanical pruning techniques (Fig. 1). Butterfly

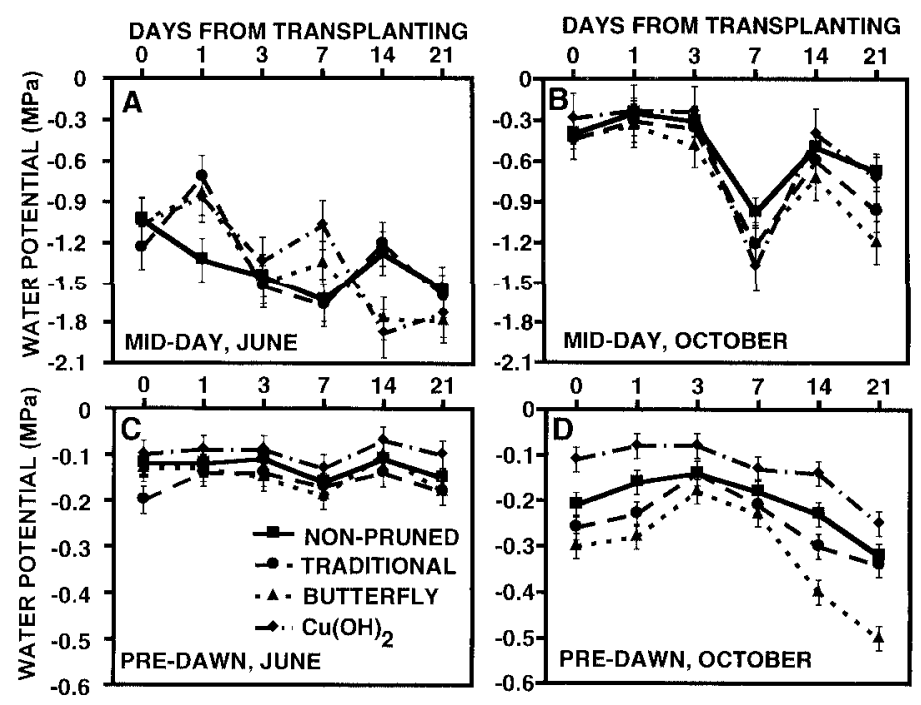

Fig 4. Mean midday (A and B) and predawn (C and D) xylem water potentials $( \pm$ standard errors) of the most recently mature leaves of Quercus shumardii seedlings following transplanting from 2.3-liter containers in June (A and C) or October (B and D). Seedlings were transplanted from nontreated containers and root pruned by traditional $(\mathbf{O})$ or butterfly $(\mathbf{\Delta})$ methods to correct root circling, or not pruned $(\boldsymbol{\square})$, or were transplanted from $\mathrm{Cu}(\mathrm{OH})_{2}$-treated containers $(\bullet)$ designed to prevent root circling. Values are observations of five plants per treatment per observation date. pruning in October resulted in the poorest predawn $\psi$ recovery on all sample dates (Fig. 4D).

Field responses. Minimal shoot elongation occurred during the first year in the field for all treatments (data not presented). October transplanted seedlings retained a height advantage over June transplanted seedlings ( $65 \mathrm{~cm}$ vs. $32 \mathrm{~cm}$ ) following two growing seasons in the field. Nonpruned and traditional root pruned seedlings remained at a similar size or exhibited slight dieback after two years in the field (Table 2). Butterfly pruning resulted in a substantial net reduction in height (Table 2), primarily due to dieback during the second growing season in the field for October transplanted seedlings (Table 1). Therefore, this practice should be avoided during transplanting of shumard oak. Cupric hydroxidetreated seedlings were the only group to gain in height and stem diameter in the field study (Table 2), mostly due to shoot growth during the second growing season (Table 1). While shoot growth in the field was unremarkable for all treatments (Table 2), $\mathrm{Cu}(\mathrm{OH})_{2}$ treated seedlings did not suffer the dieback that was observed with the other treatments (Table 2). The net result of container production and two growing seasons in the field were $\mathrm{Cu}(\mathrm{OH})_{2}$-treated seedlings that averaged $93 \mathrm{~cm}$ in height and $9.1 \mathrm{~mm}$ in stem diameter versus $43 \mathrm{~cm}$ to $18 \mathrm{~cm}$ in height and $7.1 \mathrm{~mm}$ to $4.8 \mathrm{~mm}$ in stem diameter with other treatments (Table 2). Improved posttransplant performance of $\mathrm{CuCO}_{3}$-treated seedlings compared to traditionally pruned seedlings have been reported for $F$. pennsylvanica and Q. rubra L. (Arnold and Struve, 1989b), but detailed characterization of regenerated roots and water potentials were not measured. Struve (1993) found that $Q$. rubra and $Q$. coccinea Muench. seedlings grown in $\mathrm{Cu}(\mathrm{OH})_{2}$-treated containers exhibited greater post-transplant survival and shoot growth after 3 years than nonpruned or root pruned (similar to traditional pruning in this study) seedlings, while shoot growth of Acer rubrum L. and Liquidambar styraciflua L. was unaffected.

In general, the removal of a greater root mass at transplant (Table 1) decreased post-transplant shoot growth (Table 2). Conversely, a greater number (Fig. 3A) and/or mass (Table 2) of regenerated roots during the first few weeks post-transplant increased subsequent shoot growth (Table 2). Improved root regeneration (Fig. 3A) may be associated with improved field performance via a reduction in water stress (Fig. 4) during the immediate post-transplant period. The total number of roots per plant present at observation panels was correlated with midday $\psi\left(R^{2}=0.33, P\right.$ $<0.01)$ across transplant times, root diameters, and pruning/ container treatment. The number of regenerated roots $\leq 0.5 \mathrm{~mm}$ diameter $\left(R^{2}=0.49, P \leq 0.03\right)$ and roots $>0.5 \mathrm{~mm}$ diameter $\left(R^{2}=\right.$ $0.54, P<0.01)$ were correlated with predawn $\psi$ in October.

The study presented in this paper quantitatively documents the effects of alternative mechanical and chemical solutions to the problem of circling root development in containers on root regeneration and leaf $\psi$ during immediate post-transplant establishment, and verifies that subsequent differential growth effects can persist for at least 2 years in the field. Gilman and Beeson (1995) suggested that the lack of roots, which would be in direct soil contact, immediately post-transplant at the periphery of the rootball of $\mathrm{Cu}(\mathrm{OH})_{2}$-treated seedlings might increase water stress for a short time, but $\psi$ was not measured. Such was not the case in this study (Fig. 4). Two factors that may explain this discrepancy: remedial root pruning to correct circling roots severs a large number of roots (Fig. 1), many of which are at the surface of the rootball, and the data suggests that there is a large increase in the number of small diameter roots that are regenerated from $\mathrm{Cu}(\mathrm{OH})_{2}-$ treated seedlings during the critical first weeks following transplanting (Fig. 3). Previous container production studies (Arnold 
and Struve, 1989a) have documented that a more evenly distributed fibrous root system exists in plants grown in containers coated with $\mathrm{Cu}$ that can contribute to greater water (Vartak, 1993) and mineral nutrient uptake (Arnold and Struve, 1993) compared to plants in nontreated containers. The more evenly distributed fibrous root system in the rootball and the greater number (Fig. 3) and mass (Table 2) of roots regenerated during immediate posttransplant establishment likely contribute to the observed reductions in plant water stress (Fig. 4) and thus offer a possible explanation for the increased post-transplant growth relative to nonpruned plants and those mechanically root pruned at transplant (Table 2). In a sense, $\mathrm{Cu}(\mathrm{OH})_{2}$-treated plants can be considered to be root pruned constantly during production and thus are constantly regenerating roots behind the chemically pruned root tips. These roots have already been initiated before transplanting and only need to elongate beyond the periphery of the rootball during post-transplant establishment, whereas plants that are mechanically root pruned at transplant must first initiate new roots and then these roots would elongate beyond the rootball periphery into the surrounding soil.

\section{Literature Cited}

Appleton, B.L. 1993. Nursery production alternatives for reduction or elimination of circling tree roots. J. Arboricult. 19:383-388.

Arnold, M.A. 1992. Timing, acclimation period, and cupric hydroxide concentration alter growth responses of the Ohio production system. J. Environ. Hort. 10:114-117.

Arnold, M.A., D.L. Airhart, and W.E. Davis. 1993. Cupric hydroxidetreated containers affect growth and flowering of annual and perennial bedding plants. J. Environ. Hort. 11:106-110.

Arnold, M.A. and D.K. Struve. 1993. Root distribution and mineral uptake of coarse-rooted trees grown in cupric hydroxide-treated containers. HortScience 28:988-992.

Arnold, M.A. and D.K. Struve. 1989a. Cupric carbonate controls green ash root morphology and root growth. HortScience 24:262-264.

Arnold, M.A. and D.K. Struve. 1989b. Growing green ash and red oak in $\mathrm{CuCO}_{3}$-treated containers increases root regeneration and shoot growth following transplant. J. Amer. Soc. Hort. Sci. 114:402-406.

Arnold, M.A. and E. Young. 1991. $\mathrm{CuCO}_{3}$-painted containers and root pruning affect apple and green ash root growth and cytokinin levels. HortScience 26:242-244.

Arnold, M.A. and E. Young. 1990. Use of dyes to facilitate measurement of new root growth of apple. HortScience 25:116-118.

Beeson, R.C. 1994. Water relations of field-grown Quercus virginiana Mill. from preharvest through containerization and 1 year into a landscape. J. Amer. Soc. Hort. Sci. 119:169-174.

Beeson, R.C., Jr. and R. Newton. 1992. Shoot and root responses of eighteen southeastern woody landscape species grown in cupric hydroxide-treated containers. J. Environ. Hort. 10:214-217.

Brouwer, R. 1983. Funtional equilibrium: sense or nonsense? Neth. J. Agr. Sci. 31:335-348.

Bush-Brown, J. and L. Bush-Brown. 1980. America's Garden Book. Charles Scribner Sons, New York. p. 819.

Case, G.N. and M.A. Arnold. 1993. Effects of $\mathrm{Cu}(\mathrm{OH})_{2}$-treated containers on the leaf water potential of greenhouse-grown tropical hibiscus. Southern Nurseryman's Assn. Res. Conf. Proc. 38:78-81.

Gilman, E.F. and R.J. Beeson. 1995. Copper hydroxide affects root distribution of Ilex cassine in plastic containers. HortTechnology 5:4849.

Gouin, F.R. 1983. Girdling by roots and ropes. J. Environ. Hort. 1:50-52. Harris, R.W. 1992. Arboriculture, integrated management of landscape trees, shrubs, and vines, 2nd ed. Prentice Hall, Englewood Cliffs, N.J. p. 674.

Ruter, J.M. 1994. Growth responses of four vigorous-rooted tree species in cupric hydroxide-treated containers. HortScience 29:1089.

Siebenthaler, J. 1993. Growing better trees for better landscapes. Southern Nursery Digest 27(1):36-38.

Struve, D.K. 1993. Effect of copper-treated containers on transplant survival and regrowth of four tree species. J. Environ. Hort. 11:196-199.

Struve, D.K. 1994. Street tree establishment, p. 78-88. In: G.W. Watson and D. Neely (eds.). The landscape below ground. Intl. Soc. Arbor., Savoy, Ill.

Struve, D.K., M.A. Arnold, R. Beeson, Jr., J.M. Ruter, S. Svenson, and W.T. Witte. 1994. The copper connection. Amer. Nurseryman 179(4):5261.

Svenson, S.E. and T.K. Brochat. 1992. Copper hydroxide controls root circling in container-grown west indies mahogany and carpentaria palm. TropicLine 5(5):1-4.

Svenson, S.E. and D.L. Johnston. 1995. Rooting in cupric hydroxidetreated pots affects root length and number of flowers after transplanting. HortScience 30:247-248.

Svenson, S.E., D.L. Johnston, and B.L. Coy. 1995. Shoot and root responses of eight subtropical species grown in cupric hydroxide-treated containers. HortScience 30:249-251.

Vartak, D.R. 1993. Chemical root pruning and its effects on water relations and root morphology of Photinia. MS thesis. Texas A\&M Univ., College Station. p. 112. 